\title{
Use of Bacillus Species Bacteria in Protecting the Concrete Structures from Sulphate Attack-A Review
}

\author{
Onesmus Mulwa Munyao ${ }^{\mathrm{a}, *}$, Joseph Karanja Thiong'o ${ }^{\mathrm{a}}$, Jackson Muthengia Wachira ${ }^{\mathrm{b}}$, \\ Daniel Karanja Mutitu ${ }^{b}$, Mwirichia Romano ${ }^{c}$, Genson Murithi ${ }^{b}$ \\ ${ }^{a}$ Department of Chemistry, School of Pure and Applied Sciences, Kenyatta University, Nairobi, Kenya \\ ${ }^{b}$ Department of Physical Sciences, School of Pure and Applied Sciences, University of Embu, Embu, Kenya \\ ${ }^{c}$ Department of Biological Sciences, School of Pure and Applied Sciences, University of Embu, Embu, Kenya
}

Receive Date: 27 August 2019, Revise Date: 23 October 2019, Accept Date: 31 October 2019

\begin{abstract}
:
Deleterious ions in the environment such as sulfates may degrade the concrete structures. The interaction of cement hydration products with these destructive agents contributes to severe durability threat of the concrete structures. External sulfate attack is well-known for causing permanent changes in concrete. Microbially induced calcium carbonate (MICP) precipitation has been considered as a unique technique in enhancing the durability properties of concrete. This review paper discusses the possibility of bio-deposition from MICP process as a barrier in microbial treated concrete against the penetration of sulfate ions in a sulfate- rich environment. The effect associated with chemical and physical sulfate attack is discussed in line with the mechanical properties of cement such as compressive strength whereas microscopic evaluation is based on scanning electron microscopy studies. The shortcomings associated with sulfate ions in cement-based materials and the positive effects of incorporating bacillus species bacteria in sulfate rich areas is discussed. This review found that, MICP can significantly reduce the ingress of sulfate ions in cement-based materials, which results in improving the mechanical properties of the cement mortar/concrete.
\end{abstract}

DOI: $10.33945 / \mathrm{SAMI} / \mathrm{JCR} .2019 .4 .5$

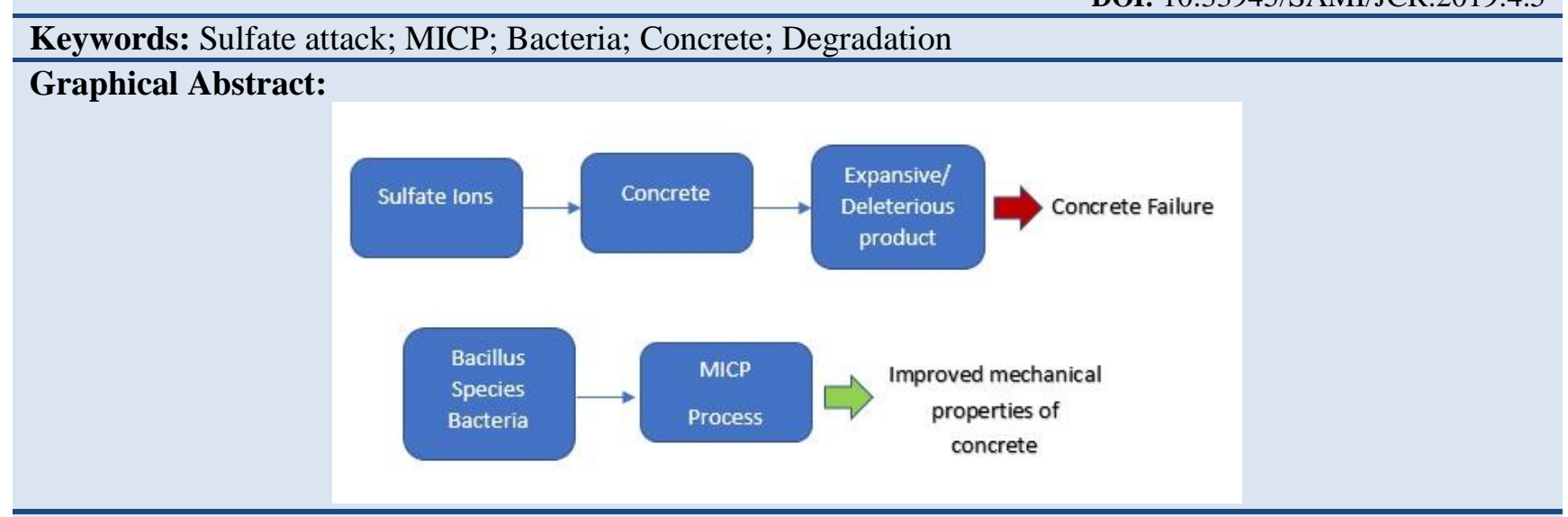

\section{Biography:}

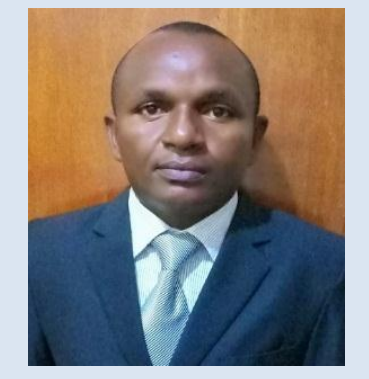

Onesmus Munyao Mulwa: He Has a MSc. Degree in Chemistry specializing in Physical and Applied Chemistry. He is currently pursuing his Ph.D in Chemistry at Kenyatta University, Kenya. The area of his research interest is Cement and Concrete Technology. Mr. Munyao has authored and co-authored several journal papers in cement and concrete. 

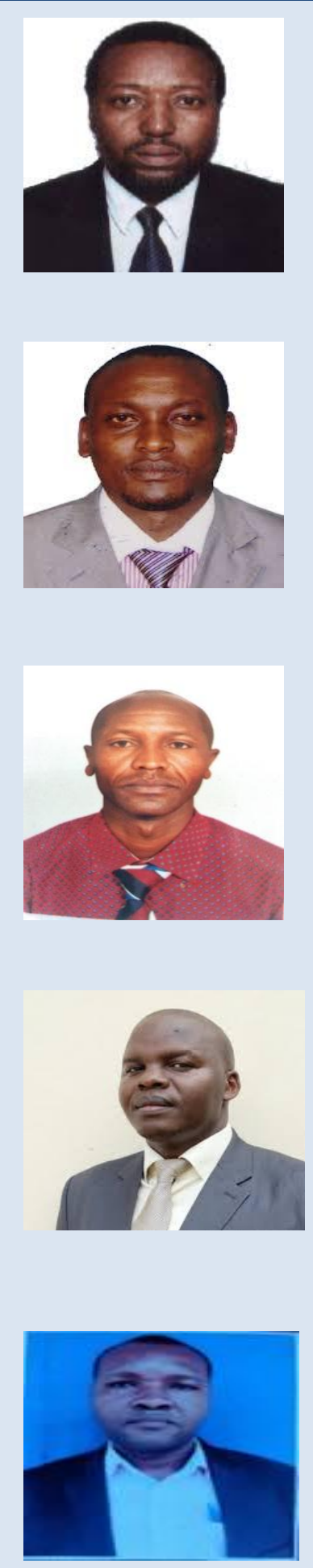

Genson Murithi: He Has Ph.D in Chemistry from Kenyatta University, Kenya. $\mathrm{He}$ is a Lecturer at University of Embu, Kenya at the Department of Physical Sciences.

\section{Introduction}

The benefits associated with concrete such as accessibility of raw materials, minimal preparation cost, high compressive strength and durability has made it to be the most affordable and widely used construction material. Large volumes of concrete are used annually across the world for construction of buildings, roads, sewer systems and bridges. While concrete is the most preferred building material, it is susceptible to the aggressive materials such as sulfates, carbon dioxide, and chlorides. The ingress of these agents into the concrete matrix causes serious durability threat on the concrete structures $[1,2]$.

Most of the concrete structures are suffering from durability threats due to the presence of micro and macro cracks that may develop during the service life of the concrete structures. These cracks form suitable pathways for the ingress of harmful substances into the concrete matrix [3, 4]. The presence of aggressive agents in the concrete matrix triggers early failure of 
the cement based structures. Amongst the discussed deleterious ions are sulfates. Sulfates are known to cause deleterious effects on cement based structures and several methods have been adopted by many researchers to reduce the sulfate attack on concrete.

Concrete structures erected in sulfate rich-environment suffer great extent of damage as a result of sulfate attack. Presence of sulfate ions in concrete structures trigger an increase in porosity, expansion, and cracking. These affects the mechanical properties and hence resulting to reduced durability of the cement based materials $[5,6]$. The placed concrete intermingles with the sulfates from the ground water resulting to dilapidation of the inherent concrete properties. This phenomenon is referred to external sulfate attack [7]. External sulfate attack caused by the ingress of sulfate ions from the environment into the concrete has been discussed in several studies [8-10]. Georges et al., 2016 [11] reported that concrete structures placed in sulfate rich areas suffers from sulfate attack. This is due to the ingress of sulfate ions into the cement matrix $[12,13]$. The mechanism of degradation of cement based materials due to the sulfate attack is now comparatively well-known $[14,15]$. Sulfate ions upon ingress into the concrete matrix can modify the chemical equilibrium between the solid phase and the interstitial phase in the cementitious matrix $[16,17]$. The chemical reaction between the hydration products of the cement and the sulfates from the environment occurs as a result of diffusion of these ions to the concrete surface $[19,20]$. Calcium hydroxide $(\mathrm{CH})$ may react with sulfates forming gypsum. The formed gypsum further reacts with tricalcium aluminate from clinker to form ettringite. Ettringitte is an expansive needle-like crystalline substance and the expansion of concrete/ mortar is associated with its formation [21, 22]. The crystallized ettringite causes expansive forces within the concrete matrix, leading to cracking and spalling [23]. The equation below shows the formation of ettringite.

$$
3 \mathrm{C} \overline{\mathrm{S}} \mathrm{H}_{2}+\mathrm{C}_{3} \mathrm{~A}+26 \mathrm{H} \rightarrow \mathrm{C}_{6} \mathrm{AS}_{3} \mathrm{H}_{32}
$$

Among the most consistent theories derived from most of the experiments with respect to sulfate attack is the crystal growth theory. This theory defines the crystallization pressure produced by supersaturation and confinement. The driving force for the crystallization according to crystal growth theory is the super saturation of the pore solution with respect to ettringite [24 - 26]. Microstructural tests have shown that the reaction of sulfates and monosulfates in pockets does not cause any expansion. However, when the pockets are depleted the finely intermixed monosulfates in the C-S-H reacts to form expansive ettringite [27]. Experimental results have shown that sulfate attack leads to not only expansion of cement based materials but also causes softening and decohesion [28, 29].

Supplementary cementitious materials (SCMs) such as fly ash, natural Pozzolana and slag have been incorporated in cement to mitigate the sulfate attack [30 - 34]. These materials however, do not effectively protect the physical sulfate attack [28, 35 and 23]. Other materials such as epoxy based fillers or silanebased water repellant have been used widely to repair concrete cracks associated with physical sulfate attack. Their short term efficiency and negative environmental impact has been an issue for the repair industry [20]. These polymeric materials are expensive and can only be applied from outside where the cracks are visible.

The precipitation of calcium carbonate by calcifying bacteria through a process referred to bio deposition has been suggested as a remarkable method for improving the durability of cement based materials. This method facilitates self-healing of concrete cracks reducing the risks of harmful materials from ingression into the concrete [36]. Chigozirim et al., [37] defined microbially induced calcium carbonate precipitation (MICP) as the ability of microbes to produce calcium carbonate extracellularly through a metabolic activity. Several researchers have shown the potential of using calcifying bacteria via biominerization to improve the durability of cement-based materials [38-40].

\section{Biomineralisation}

Mineralisation used in civil engineering often refers to production of minerals, primarily carbonate products. Chigozirim et al. [37] defined biomineralisation as the process by which living organisms produce minerals through metabolic activities from their interaction with the environment. In biomineralisation, living organisms produces inorganic mineral phases with a biopolymer [41]. The involved microorganisms secrete one or more metabolic products that react with ions or compounds in the environment resulting in the subsequent deposition of mineral particles as metabolic products [42]. These metabolic activities may result in selective cementation by producing moderately insoluble organic and inorganic compounds.

The formed compounds which can serve as cementitious materials are referred to biocement.

Biocement comprising of an alkalophilic microbe, substrate solution and calcium ion solution has attracted much attention as a 'green' "material. It relies on microbially induced calcium carbonate precipitation (MICP) [43]. Many researchers have shown that MICP can improve the concrete strength and durability of cement-based materials [44-46]. The process involves enzymatic reactions. Urease produced by the bacteria hydrolyses urea, and calcium is utilized as energy source to form biocement [47]. 
In MICP process, microorganisms play a key role in maintaining an alkaline environment via their innumerable physiological activities. These activities ensure an increase in $\mathrm{pH}$ and dissolved inorganic carbon [48]. Rong et al., [49] and Ariyanti et al., [48] reported that biocementation can be effective in binding sand grains for making bio sands of adequate compressive strength as shown in Figure 1. Ghosh et al., [50] reported compressive strength increasing up to $25 \%$ when pure mortar was mixed with shewanella species. The increase in compressive strength was attributed to biocementation.

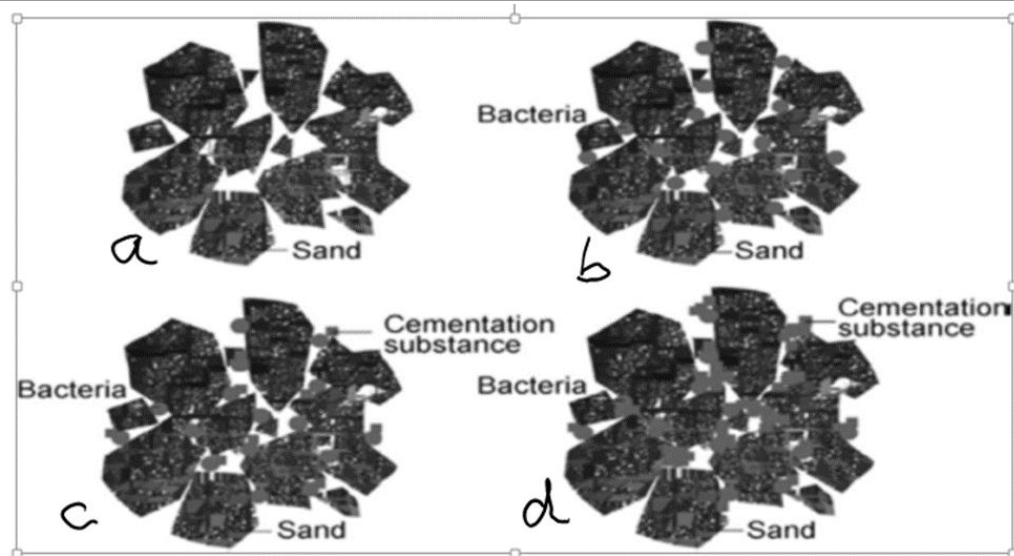

Figure 1. Cementation mechanism of biocement. (a) Loose sand; (b) bacteria absorbed in the surface of loose sand; (c) cementation substance absorbed in the surface of loose sand; (d) loose sand to whole sand cemented by bio-cement.

Ureolytic activity involves consumption of urea to form ammonia and carbamate. The formed carbamate spontaneously hydrolyses to form an additional ammonia and carbonic acid [51]. The formed products trigger formation of bicarbonate, increasing the $\mathrm{pH}$ that ultimately shifts the bicarbonate equilibrium resulting to formation of carbonate ions. As a result of high $\mathrm{pH}$ in the cell, there is need for a high extracellular calcium ion concentration and a low extracellular proton concentration to facilitate the secretion of carbonate ions. High $\mathrm{pH}$ favors the formation of carbonates from bicarbonates [52, 47]). Equations 2-8 reveals the mechanism of ureolytic activity.

$$
\begin{aligned}
& \mathrm{CO}\left(\mathrm{NH}_{2}\right)_{2}+\mathrm{H}_{2} \mathrm{O} \rightarrow \mathrm{NH}_{2} \mathrm{COOH}+\mathrm{NH}_{3} \\
& \mathrm{NH}_{2} \mathrm{COOH}+\mathrm{H}_{2} \mathrm{O} \rightarrow \mathrm{NH} 3+\mathrm{H}_{2} \mathrm{CO}_{3} \\
& \mathrm{H}_{2} \mathrm{CO} 3 \leftrightarrow \mathrm{HCO}_{3}{ }^{-}+\mathrm{H}^{+} \\
& 2 \mathrm{NH}_{3}+2 \mathrm{H}_{2} \mathrm{O} \leftrightarrow 2 \mathrm{NH}_{4}^{+}+2 \mathrm{OH}^{-} \\
& \mathrm{HCO}_{3}{ }^{-}+\mathrm{H}^{+}+2 \mathrm{NH}_{4}^{+}+2 \mathrm{OH}^{-} \leftrightarrow \mathrm{CO}_{3}^{2-}+2 \mathrm{NH}_{4}^{+}+2 \mathrm{H}_{2} \mathrm{O} \\
& \mathrm{Ca}^{2+}+\mathrm{Cell} \rightarrow \mathrm{Cell}^{2}-\mathrm{Ca}^{2+} \\
& \mathrm{Cell}-\mathrm{Ca}^{2+}+\mathrm{CO}_{3}{ }^{2-} \rightarrow \mathrm{Cell}-\mathrm{CaCO}_{3}
\end{aligned}
$$

Carbonic anhydrase enzyme assists the interconversion of carbon dioxide and bicarbonate and promotes the precipitation of calcium carbonate [53].Carbonic anhydrase plays a vital role in concentration of $\mathrm{CO}_{2}$. Equations 9-10 show how the carbonic anhydrase in presence of bicarbonate as the source of the dissolved inorganic carbon catalyses bicarbonate into carbon dioxide [54].

$$
\begin{aligned}
& \mathrm{HCO}_{3}{ }^{-} \rightarrow \mathrm{H}_{2} \mathrm{O}+\mathrm{CO}_{2} \\
& \mathrm{Ca}^{2+}+2 \mathrm{HCO}_{3}{ }^{-} \rightarrow \mathrm{CaCO}_{3}+\mathrm{H}^{+}+\mathrm{HCO}_{3}{ }^{-}
\end{aligned}
$$

\subsection{Biodeposition/ Bioremediation}

MICP deposits carbonate crystals inside the surface pores of cement-based materials preventing the ingress of external deleterious materials into the concrete matrix [55]. Several researchers have explored MICP for protection and consolidation of ornamental limestone [56]. Biodeposition treatment has been applied in five different types of limestone to investigate the effect of pore structure on the protective performance of a MICP based surface treatment [57]. It was also found that biodeposition reduced water absorption and gas permeation on cementitious materials.

D. Muynck reported that decrease in capillary suction and decrease in gas permeability was a result of deposition of calcite layer on surface of the cement [45]. Biodeposition results in plugging of pores and formation of biofilms on the surface of cement based materials. MICP technique has been used to remove sulphate and clean crusts from marble monuments [58]. Desulfovibrio desulfuricans an anaerobic bacterium converted calcium sulphate into calcium carbonate as product of MICP as shown in Equation 11 [59].

$6 \mathrm{CaSO}_{4}+4 \mathrm{H}_{2} \mathrm{O}+6 \mathrm{CO}_{2} \rightarrow 6 \mathrm{CaCO}_{3}+4 \mathrm{H}_{2} \mathrm{~S}+2 \mathrm{~S}+11 \mathrm{O}_{2}$

Bioremediation in concrete materials has been carried out in two ways. Firstly the bacteria cells with proper nutrition, urea and calcium source are assimilated into the concrete matrix during casting. In this scenario, the microbes trigger the formation of biominerals when the cracks occur. The biominerals forms calcites that seal the cracks [60]. The second method involves 
application of the bacteria cell on the surface of the concrete cracks. From the previous studies carried out by [44] SEM scans showed calcite precipitation in healing areas of cement mortar surface where cracks of width of $3 \mathrm{~mm}$ and depth of $18.8 \mathrm{~mm}$ in mortars were healed by Sporosarcina pasteurii.

Ramachandran et al., [44] initiated the MICP based bioremediation of concrete materials. Sand mixed with Sporosarcina pasteurii cell were applied in cracks in mortars to improve the compressive strength by $61 \%$. In a separate experiment, Ramachandran et al., [44] employed polyurethane -encapsulated bacterial cells in order to protect the bacteria cells from the high $\mathrm{pH}$ of cement [61]. There was a significant increase in compressive strength of the remediated concrete of $12 \%$ at 7 days and only $3 \%$ increase at 28 days. The sealing of cracks by calcite precipitated by B. sphaericus resulted in reduction of water permeability and crack bridging was demonstrated by an increase in ultra-sonic pulse velocity [62]. Table 1 summarizes the bioremediation efficiencies in crack healing of cementitious materials as reported by several authors.

Table 1. Bioremediation efficiency of crack healing on cementitious materials based on MICP technology

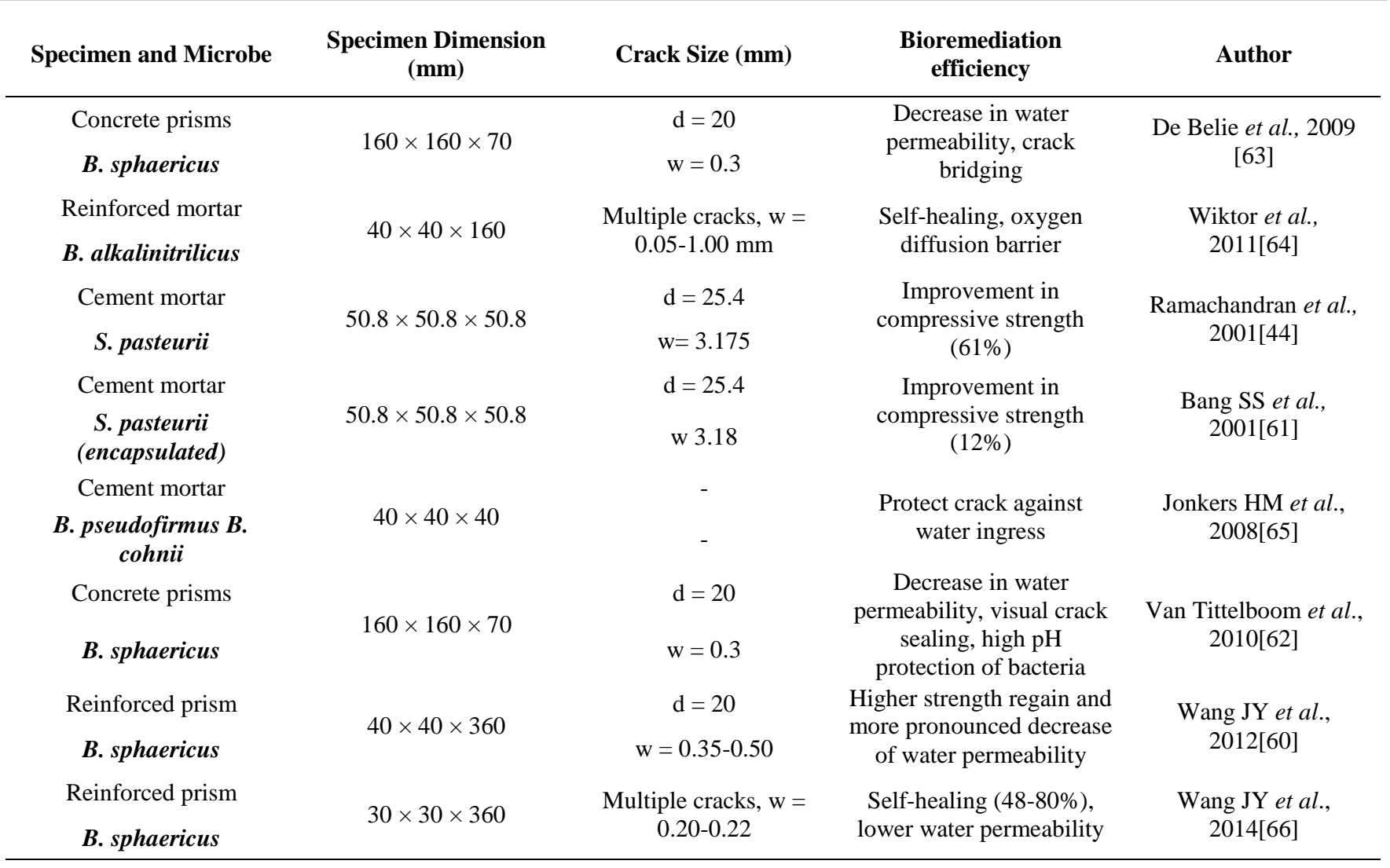

\section{Effects of Sulphate Attack on Cement Based Materials}

In this segment, we summarize the results obtained so far on the effects associated with sulphate attack on the cement -based materials when exposed to sulphate solutions.

\subsection{Chemical Sulphate Attack}

\subsubsection{Compressive Strength}

According to Joshi et al. findings [67], the performance of cement both mortar prisms and concrete cubes were subjected to sulphate environment using the outlined exposure regimes (as shown in Table 2). Concentrations of the nutrient broth medium, urea and calcium were $1.3 \% \mathrm{w} / \mathrm{v}, 2 \% \mathrm{w} / \mathrm{v}$ and $25 \mathrm{mM} \mathrm{w} / \mathrm{v}$, respectively.
It was found that, the compressive strength of test cements treated and cured with bacteria solutions indicated as BAT and BST increased as compared to the blank. The treated test cements exhibited 35\% increase in compressive strength while the test cement cured through spraying with bacteria solution gave an increase in compressive strength up to $16 \%$ as compared to the control test cements. The authors attributed the compressive strength increase to biocementation. Mittermayr et al., [68] showed that the increase in compressive strength could be as a result of densification of cementitious matrix at microstructural level. Najjar et al., [69] in their work reported that ingress of sulfate ions into the concrete matrix triggers the formation of expansive products that fills the pores and voids leading to the densification of microstructure 
Table 2. Exposure of test cements (concrete cubes and mortar prisms) in both blank and bacterial solutions

\begin{tabular}{lll} 
Specimens & Material Used & Mechanism of curing \\
\hline & Cement:Sand:Course Aggregate, & \\
Control Sample & Water/Cement $\mathrm{r}=0.5$ & Water curing for 28 days
\end{tabular}

Concrete Cubes

Bacterial admixed treated (BAT)

Bacterial treated (BST)

Control Sample

Mortar Prisms

Bacterial Admixed Mortar (BAM)

Bacterial mortar (BSM) spray Cement:Sand:Course aggregate,

Water/ cement $=0.5$

Cement:Sand, $=0.47$

Cement: Sand

Bacterial

culture/ cement $=0.47$

Cement:Sand $=0.47$

Water/cement
Submersion in NB media, urea $\mathrm{CaCl}_{2}$ and bacterial culture for 28 days

Bacterial spray on specimens twice a day till 28 days

Water curing for 28days

Submersion in NB media, Urea $\mathrm{CaCl}_{2}$ and bacterial culture for 28days

Bacterial Spray on specimens twice a day till 28 days during the initial exposure of concrete to sulfate rich areas.

Summit et al., [67] observed severe strength loss in control test cement after 12 months of exposure to sulphate solutions. The compressive strength of the control test cement (blank) decreased by $30 \%$ as compared to the initial strength before exposure while the bacteria treated test cement showed no significant drop in strength. This decrease in strength was attributed to increased penetration of sulfate salts initiating higher buildup of expansive products in the pores of the control test cements. Formation of ettringite crystals reduces the quantity of $\mathrm{CH}$ and $\mathrm{C}_{3} \mathrm{~A}$ of the cementitious matrix and the salt crystallization pressure within the pores of the cement mortar [70, 71]. Several other authors have also shown the increase in compressive strength as a result of incorporating bacteria [72-75].

While the studies are based on simulated laboratory experiments, it would be necessary if beneficial bacteria were incorporated into a sulfate rich environment where biodegrading bacteria are present such as sewage set up. This would help establish whether it would be suitable to introduce the remedial bacteria during the mixing as mix water or use the remedial bacteria solution in curing the concrete.

\subsubsection{Visual Appearance/ Observations}

The studies conducted by [67] clearly showed distinct difference in control specimens versus bacterial treated specimens when subjected into sulfate solutions. According to the authors there was clear sign of degradation of the control specimen after 12 months of exposure to sulfate solution. The bacterial treated specimen did not show any sign of degradation. Figures 2, 3 and 4 show the appearance of control specimens, BAT and BST respectively when exposed to sulfate solutions. These results are according to Sumit et al., findings [67].

\subsubsection{Change in Mass}

Ingress of sulfate ions into the cement mortar/ concrete causes increase in mass by about $0.8 \%$ [67]. Maes et $a l .$, [76] reported that the increase in mass of concrete / mortar exposed to sulphates could be attributed to the formation of expansive products. The authors argued that the sulphate ions reacts with the hydration products leading to compacted microstructure. According to [77] a high porous concrete gains more mass due to high rate of sulphate ions ingress. Najjar et al., [78] reported that higher pore volume contributes to the transportation of sulfate ions hence filling of concrete pores with expansive products. 

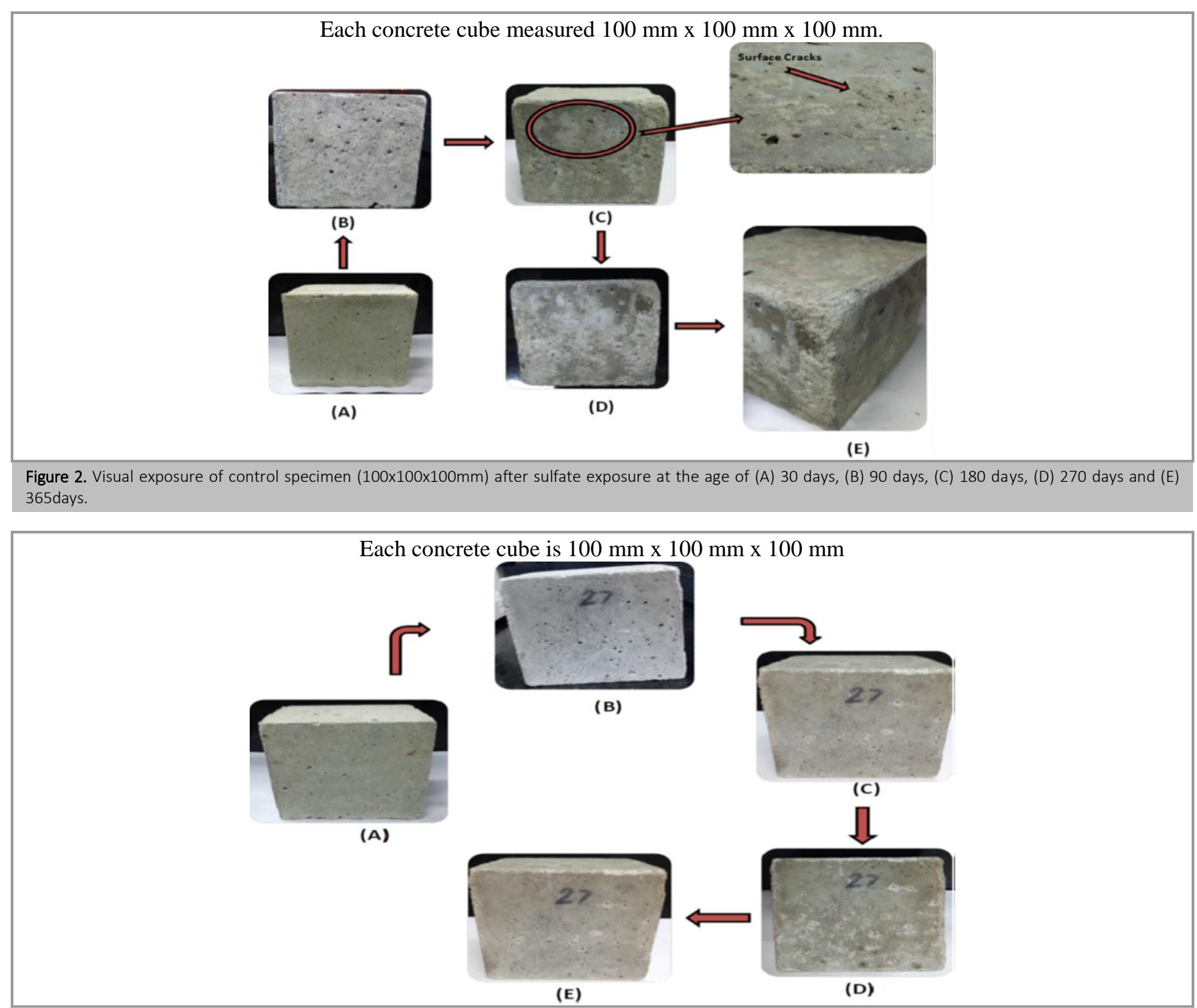

Figure 3. Visual Appearance of BAT specimen $(100 \times 100 \times 100 \mathrm{~mm})$ after sulfate exposure at the age of (A) 30 days, (B) 90 days, (C) 180 days, (D) 270 days and (E) 365 days

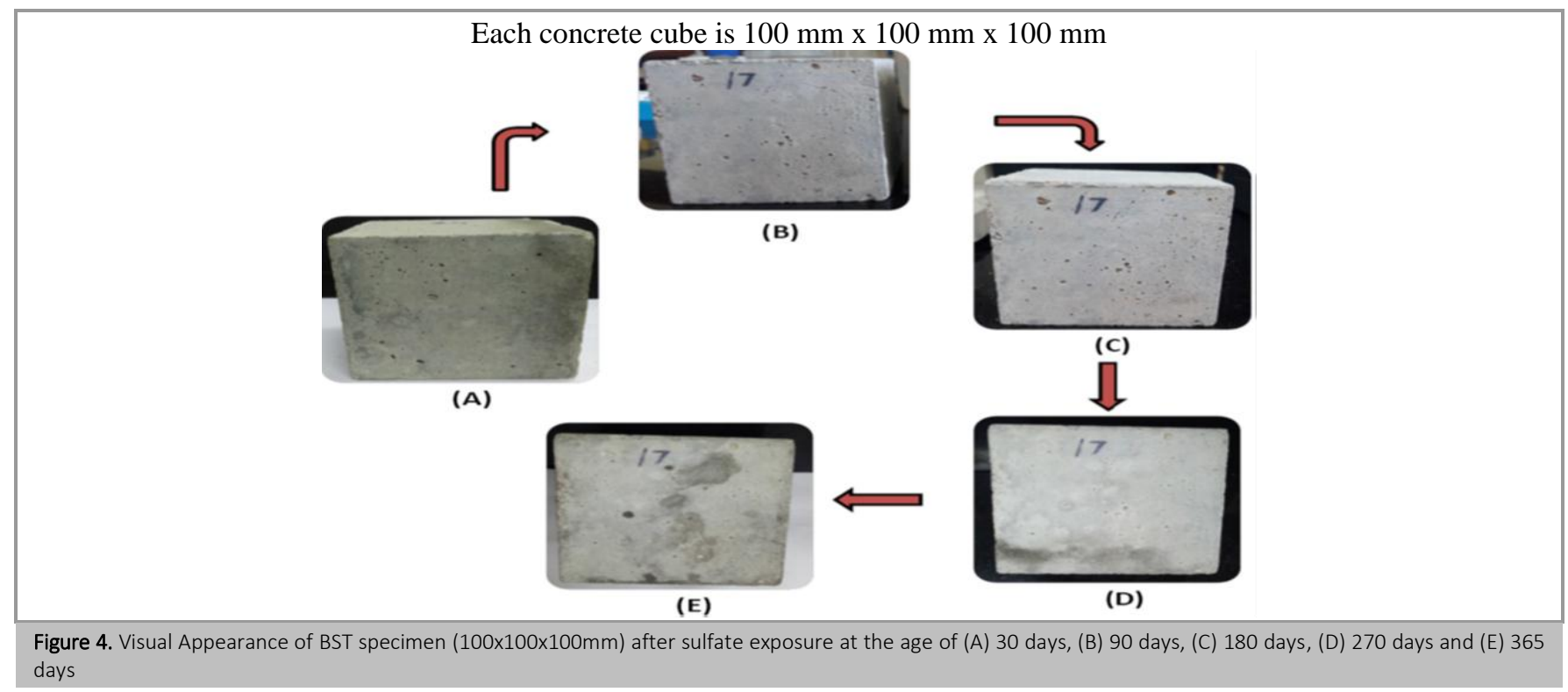




\subsection{Physical Sulfate Attack}

Cement based materials are prone to physical sulfate attack. This attack to the concrete/ cement mortar is characterized by formation of salt efflorescence on the surface of the concrete/ mortar. Nehdi et al., [77] reported that deterioration mechanism in physical sulfate attack is due to stress development from the salt crystallization pressure in the pore structure. Sulfate ions penetrates into the concrete pores through capillary suction [79]. Sulfate salts crystallizes on the concrete surface since at the upper dry surface, the rate of evaporation exceeds the rate of capillary rise. Scherer G.W. reported that salt solution uptake into the pores by capillary pressure is dependent on the pore distribution of porous body as well as its wetting behavior [80].

According to Sumit et al., [67] thick deposition of salt efflorescence was observed on the upper surface of the control specimens. The authors further noted that there was a crack developed on the control specimens after 90 days of exposure. The bacterial treated specimens showed excellent resistant to sulfate attack. There was no visible damage such as surface scaling or crack formation observed in the bacteria treated samples (BSM and BAM) as indicated in Table 2. The authors attributed the resistance to calcite precipitation. The figures below show the influence of physical sulfate attack as reported by Joshi et al. (Figures 5, 6 and 7) [67].

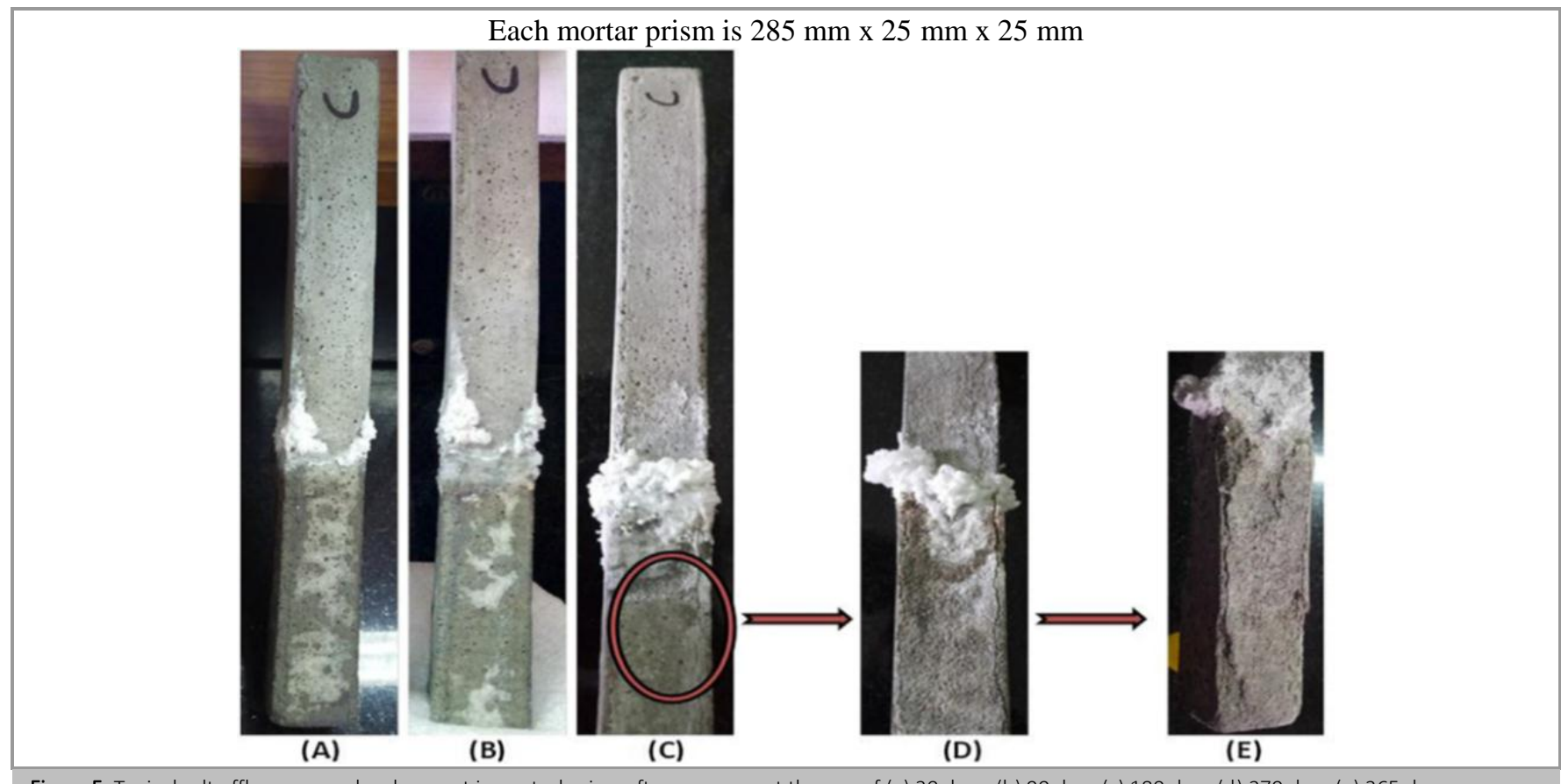

Figure 5. Typical salt efflorescence development in control prism after exposure at the age of (a) 30 days, (b) 90 days (c) 180 days (d) 270 days (e) 365 days.

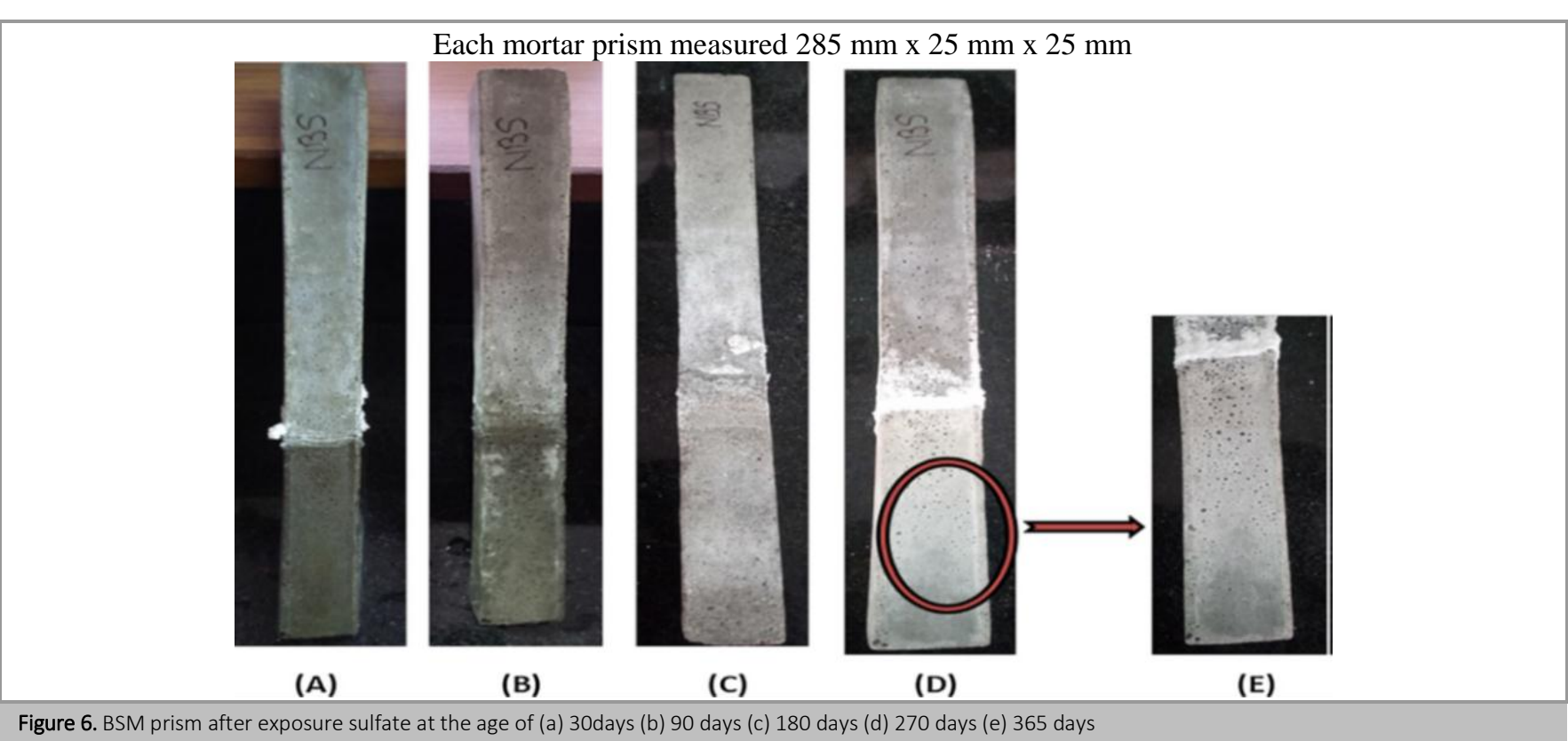

Figure 6. BSM prism after exposure sulfate at the age of (a) 30days (b) 90 days (c) 180 days (d) 270 days (e) 365 days 


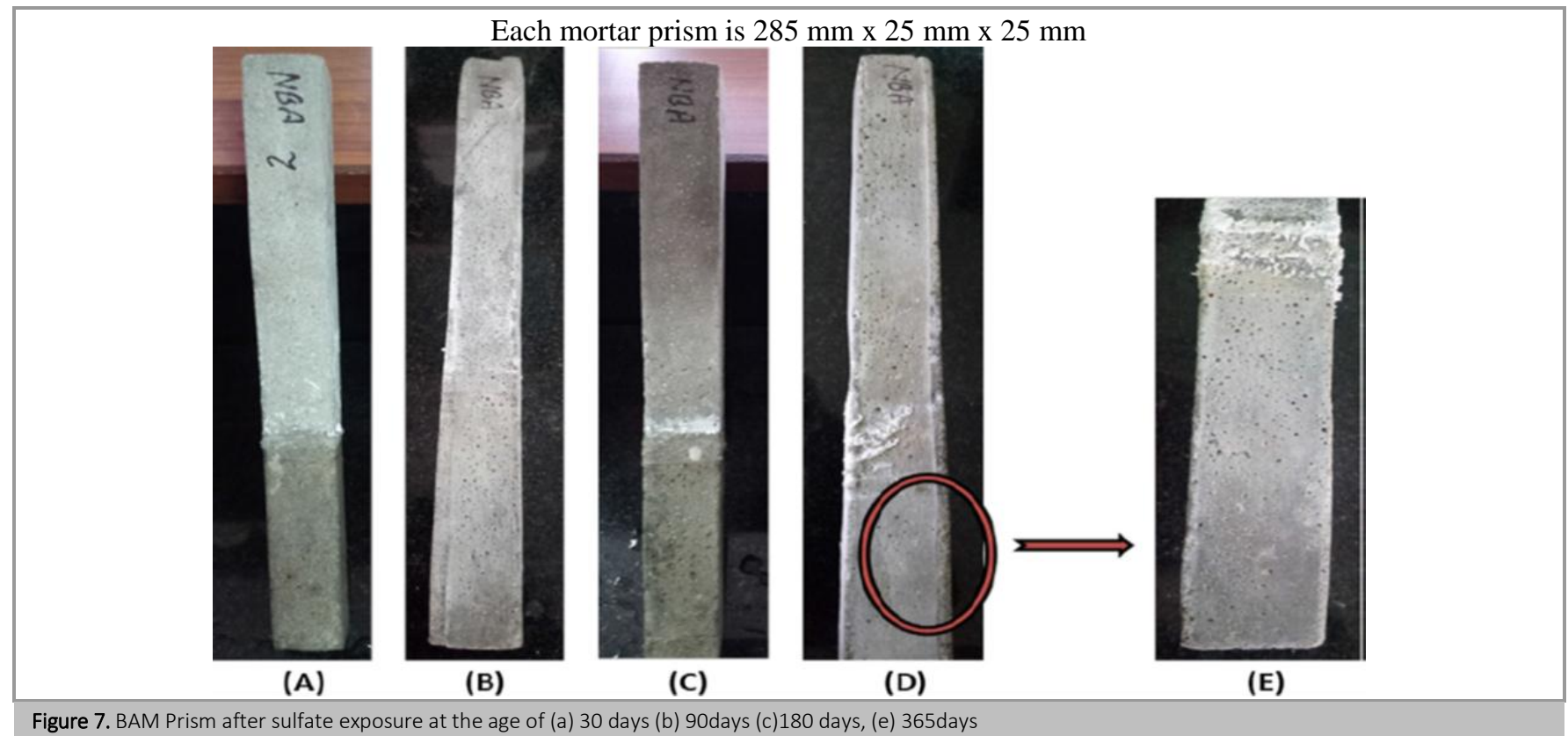

\subsection{Microscopic Evaluation}

Summit et al. [67] reported increased ettringite formation at the age of 90 days in control specimens cured in sodium sulfate solution, whereas the bacterial cured specimens exhibited increased calcium carbonate formations. The growth of calcite might be attributed to MICP. In other studies, [81-84] SEM results showed that the concrete mixed with bacteria had improved the microstructure which was attributed to calcite precipitation by the bacteria. According to Iheanyichukwu and Vijay reports [37, 85], the incur- poration of bacteria into the concrete improved the overall microstructure of the concrete. The calcite precipitation filled the pores of the concrete reducing any ingress of external materials such as sulphates. Figure 8 depicts an example of SEM images for concrete with and without bacteria solution [37].

As seen in Figure 8, concrete with bacteria showed improved morphology as opposed to plain concrete. The authors attributed this behavior to calcite precipitation by the bacteria.

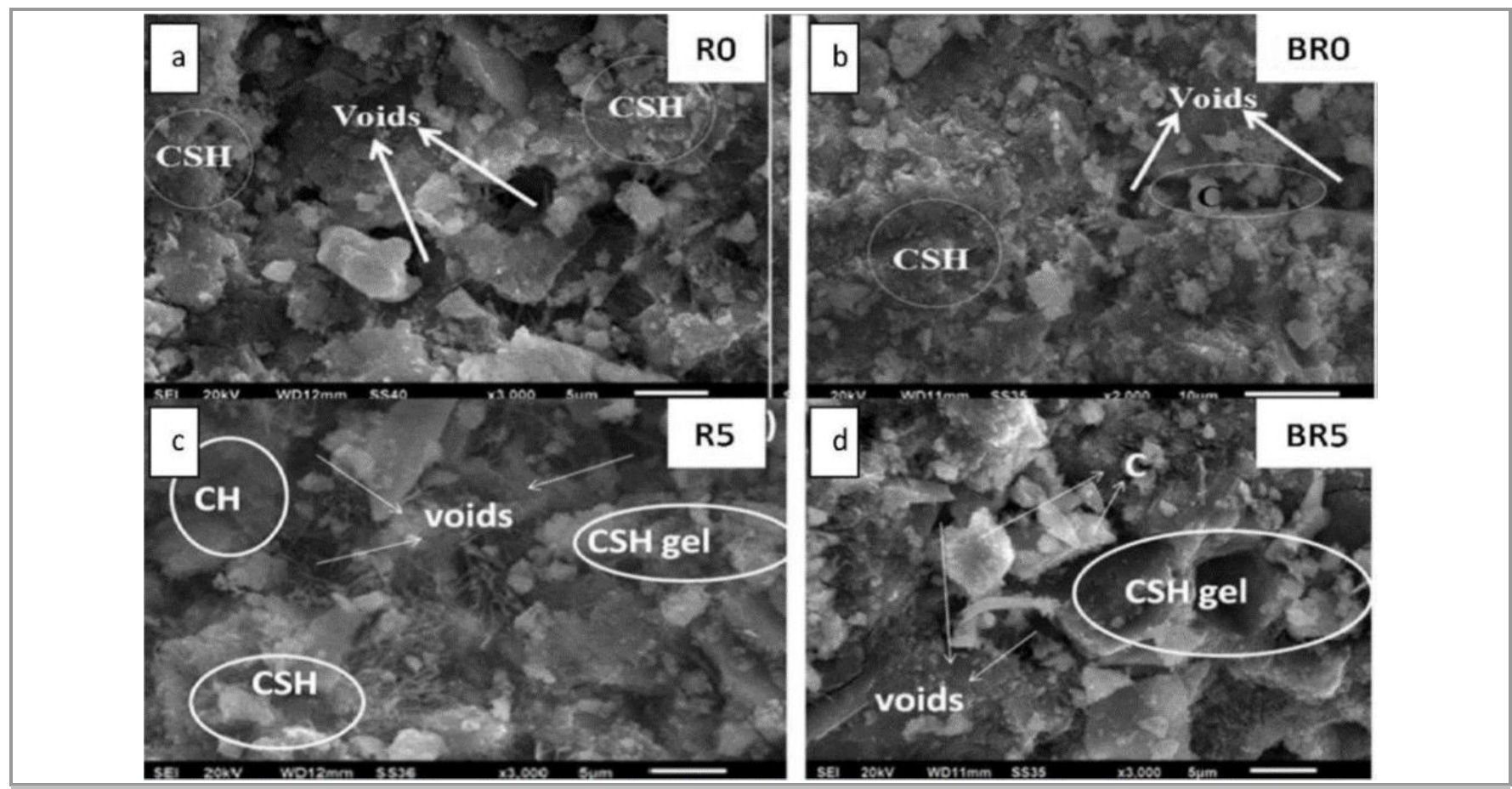

Figure 8. SEM images showing (a) Normal concrete, (b) Bacterial concrete, (c) 5\% RHA concrete, and (d) Bacterial concrete with 5\% RHA [85]. 


\section{Conclusion}

This review work has established that cement- based materials exposed to sulfate rich-environment are prone to chemical and physical sulfate attack. Durability of such structures is reduced significantly. Further, it was shown that MICP improves the mechanical properties of cement-based materials. As such, the ingress of sulfate ions in microbial treated concrete/ mortar is reduced significantly resulting to increased compressive strength. However, it was found that there is a need for conducting more research about the use of remedial bacteria in environment with deleterious bacteria. This includes environment with sulfate bacteria such as sewage cases. Many structures have failed especially in Kenya in such environments where remedial measures have not been taken early in advance. Such cases may involve preparation of concrete with remedial bacteria.

\section{Acknowledgment}

Access of scholarly repository and library materials from Kenyatta University and University of Embu, Kenya is greatly appreciated.

\section{Disclosure statement}

No potential conflict of interest was reported by the authors.

\section{References}

[1] Parastegari, N., Mostofinejad, D., \& Poursina, D. (2019). Use of bacteria to improve electrical resistivity and chloride penetration of air-entrained concrete. Construction and Building Materials, 210, 588-595.

[2] Joshi, S., Goyal, S., Mukherjee, A., \& Reddy, M. S. (2019). Protection of concrete structures under sulfate environments by using calcifying bacteria. Construction and Building Materials, 209, 156-166.

[3] Basheer, L., Kropp, J., \& Cleland, D. J. (2001). Assessment of the durability of concrete from its permeation properties: a review. Construction and building materials, 15(2-3), 93-103.

[4] Aguiar, J. L., Camões, A., \& Moreira, P. (2008). Performance of concrete in aggressive environment. International journal of concrete structures and materials, 2(1), 21-25.

[5] Ouyang, W. Y., Chen, J. K., \& Jiang, M. Q. (2014). Evolution of surface hardness of concrete under sulfate attack. Construction and Building Materials, 53, 419-424.

[6] Liu, T., Zou, D., Teng, J., \& Yan, G. (2012). The influence of sulfate attack on the dynamic properties of concrete column. Construction and Building Materials, 28(1), 201-207.

[7] Leemann, A., \& Loser, R. (2011). Analysis of concrete in a vertical ventilation shaft exposed to sulfate-containing groundwater for 45 years. Cement and Concrete Composites, 33(1), 7483.

[8] Macphee, D. E., \& Barnett, S. J. (2004). Solution properties of solids in the ettringite-thaumasite solid solution series. Cement and Concrete Research, 34(9), 1591-1598.

[9] Neville, A. (2004). The confused world of sulfate attack on concrete. Cement and Concrete research, 34(8), 1275-1296.

[10] Santhanam, M., Cohen, M. D., \& Olek, J. (2002). Mechanism of sulfate attack: A fresh look: Part 1: Summary of experimental results. Cement and concrete research, 32(6), 915-921.

[11] Massaad, G., Rozière, E., Loukili, A., \& Izoret, L. (2016). Advanced testing and performance specifications for the cementitious materials under external sulfate attacks. Construction and Building Materials, 127, 918-931.

[12] Ouyang, C., Nanni, A., \& Chang, W. F. (1988). Internal and external sources of sulfate ions in Portland cement mortar: two types of chemical attack. Cement and Concrete Research, 18(5), 699709.

[13] Liu, Z., Zhang, F., Deng, D., Xie, Y., Long, G., \& Tang, X. (2017). Physical sulfate attack on concrete lining-A field case analysis. Case studies in construction materials, 6, 206-212.

[14] Skalny, J., \& Pierce, J. (1999). Sulfate attack: an overview. Materials Science of Concrete: Sulfate Attack Mechanisms, J. Marchand and JP Skalny, eds., The American Ceramic Society, 49-64.

[15] Santhanam, M., Cohen, M. D., \& Olek, J. (2002). Mechanism of sulfate attack: A fresh look: Part 1: Summary of experimental results. Cement and concrete research, 32(6), 915-921.

[16] Glasser, F. P. (2009). Keynote paper: The thermodynamics of attack on Portland cement with special reference to sulfate. Concrete in aggressive aqueous environments-Performance, Testing, and Modeling, 3-17.

[17] Taylor, H. F. W. (1994). Sulfate reactions in concrete--microstructural and chemical aspects. Ceramic Transactions, 40 pp., 61 .

[18] Thorvaldson, T. (1954). Chemical aspects of the durability of cement products, in: Proceedings of $3^{\text {rd }}$ International Symposium on the Chemistry of cement, Cement and Concrete Association, London.

[19] Whittaker, M., \& Black, L. (2015). Current knowledge of external sulfate attack. Advances in Cement Research.

[20] Suleiman, A. R., Soliman, A. M., \& Nehdi, M. L. (2014). Effect of surface treatment on durability of concrete exposed to physical sulfate 
attack. Construction and Building Materials, 73, 674-681.

[21] Mehta, P. K. (1973). Mechanism of expansion associated with ettringite formation. Cement and concrete research, 3(1), 1-6.

[22] Feng, P., Garboczi, E. J., Miao, C., \& Bullard, J. W. (2015). Microstructural origins of cement paste degradation by external sulfate attack. Construction and building materials, 96, 391-403.

[23] Nehdi, M. L., Suleiman, A. R., \& Soliman, A. M. (2014). Investigation of concrete exposed to dual sulfate attack. Cement and Concrete Research, 64, 42-53.

[24] Scherer, G. W. (2000). Reply to the discussion by S. Chatterji of the paper,"Crystallization in pores". Cement and Concrete Research, 30(4), 673675.

[25] Scherer, G. W. (2004). Stress from crystallization of salt. Cement and concrete research, 34(9), 1613$1624 .$.

[26] Müllauer, W., Beddoe, R. E., \& Heinz, D. (2013). Sulfate attack expansion mechanisms. Cement and concrete research, 52, 208-215.

[27] Yu, C., Sun, W., \& Scrivener, K. (2013). Mechanism of expansion of mortars immersed in sodium sulfate solutions. Cement and concrete research, 43, 105-111.

[28] Chabrelie, A. (2010). Mechanisms of degradation of concrete by external sulfate ions under laboratory and field conditions (No. THESIS). EPFL.

[29] El-Hachem, R., Rozière, E., Grondin, F., \& Loukili, A. (2012). Multi-criteria analysis of the mechanism of degradation of Portland cement based mortars exposed to external sulphate attack. Cement and Concrete Research, 42(10), 1327-1335.

[30] Irassar, E. F., Gonzalez, M., \& Rahhal, V. (2000). Sulphate resistance of type $\mathrm{V}$ cements with limestone filler and natural pozzolana. Cement and Concrete Composites, 22(5), 361-368.

[31] Uysal, M., \& Sumer, M. (2011). Performance of self-compacting concrete containing different mineral admixtures. Construction and Building materials, 25(11), 4112-4120.

[32] Barcelo, L., Gartner, E., Barbarulo, R., Hossack, A., Ahani, R., Thomas, M., ... \& Blair, B. (2014). A modified ASTM C1012 procedure for qualifying blended cements containing limestone and SCMs for use in sulfate-rich environments. Cement and Concrete Research, 63, 75-88.

[33] Higgins, D. D., \& Crammond, N. J. (2003). Resistance of concrete containing ggbs to the thaumasite form of sulfate attack. cement and concrete Composites, 25(8), 921-929..

[34] Skaropoulou, A., Sotiriadis, K., Kakali, G., \& Tsivilis, S. (2013). Use of mineral admixtures to improve the resistance of limestone cement concrete against thaumasite form of sulfate attack. Cement and Concrete Composites, 37, 267275.

[35] Irassar, E. F., Di Maio, A., \& Batic, O. R. (1996). Sulfate attack on concrete with mineral admixtures. Cement and Concrete Research, 26(1), 113-123.

[36] Wiktor, V., \& Jonkers, H. M. (2015). Field performance of bacteria-based repair system: Pilot study in a parking garage. Case Studies in Construction Materials, 2, 11-17.

[37] Iheanyichukwu, C. G., Umar, S. A., \& Ekwueme, P. C. (2018). A Review on Self-Healing Concrete Using Bacteria. Sustainable Structures and Materials, An International Journal, 1(1), 12-20.

[38] Joshi, S., Goyal, S., \& Reddy, M. S. (2018). Influence of nutrient components of media on structural properties of concrete during biocementation. Construction and Building Materials, 158, 601-613.

[39] Joshi, S., Goyal, S., Mukherjee, A., \& Reddy, M. S. (2017). Microbial healing of cracks in concrete: a review. Journal of industrial microbiology \& biotechnology, 44(11), 1511-1525.

[40] Seifan, M., \& Berenjian, A. (2018). Application of microbially induced calcium carbonate precipitation in designing bio self-healing concrete. World Journal of Microbiology and Biotechnology, 34(11), 168.

[41] Chen, P. Y., McKittrick, J., \& Meyers, M. A. (2012). Biological materials: functional adaptations and bioinspired designs. Progress in Materials Science, 57(8), 1492-1704.

[42] Frankel, R. B., \& Bazylinski, D. A. (2003). Biologically induced mineralization by bacteria. Reviews in mineralogy and geochemistry, 54(1), 95-114.

[43] Rong, H., \& Qian, C. (2012). Characterization of microbe cementitious materials. Chinese science bulletin, 57(11), 1333-1338.

[44] Ramachandran, S. K., Ramakrishnan, V., \& Bang, S. S. (2001). Remediation of concrete using microorganisms. ACI Materials Journal-American Concrete Institute, 98(1), 3-9.

[45] De Muynck, W., Cox, K., De Belie, N., \& Verstraete, W. (2008). Bacterial carbonate precipitation as an alternative surface treatment for concrete. Construction and Building Materials, 22(5), 875-885.

[46] Achal, V., Mukherjee, A., \& Reddy, M. S. (2010). Microbial concrete: way to enhance the durability of building structures. Journal of materials in civil engineering, 23(6), 730-734.

[47] Achal, V., \& Mukherjee, A. (2015). A review of microbial precipitation for sustainable construction. Construction and Building Materials, 93, 1224-1235.

[48] Dessy, A., Abyor, N., \& Hadi, H. (2011). An overview of biocement production from 
microalgae. International Journal of Science and Engineering, 2(2), 31-33.

[49] Rong, H., Qian, C. X., \& Li, L. Z. (2012). Study on microstructure and properties of sandstone cemented by microbe cement. Construction and Building Materials, 36, 687-694.

[50] Ghosh, P., Mandal, S., Chattopadhyay, B. D., \& Pal, S. (2005). Use of microorganism to improve the strength of cement mortar. Cement and Concrete Research, 35(10), 1980-1983.

[51] Burne, R. A., \& Chen, Y. Y. M. (2000). Bacterial ureases in infectious diseases. Microbes and Infection, 2(5), 533-542.

[52] Knoll, A. H. (2003). Biomineralization and evolutionary history. Reviews in mineralogy and geochemistry, 54(1), 329-356.

[53] Mobley, H. L., \& Hausinger, R. P. (1989). Microbial ureases: significance, regulation, and molecular characterization. Microbiology and Molecular Biology Reviews, 53(1), 85-108.

[54] Li, W., Liu, L., Chen, W., Yu, L., Li, W., \& Yu, H. (2010). Calcium carbonate precipitation and crystal morphology induced by microbial carbonic anhydrase and other biological factors. Process Biochemistry, 45(6), 1017-1021.

[55] Phillips, A. J., Lauchnor, E., Eldring, J., Esposito, R., Mitchell, A. C., Gerlach, R., ... \& Spangler, L. H. (2012). Potential CO2 leakage reduction through biofilm-induced calcium carbonate precipitation. Environmental science \& technology, 47(1), 142-149.

[56] De Muynck, W., Leuridan, S., Van Loo, D., Verbeken, K., Cnudde, V., De Belie, N., \& Verstraete, W. (2011). Influence of pore structure on the effectiveness of a biogenic carbonate surface treatment for limestone conservation. Appl. Environ. Microbiol., 77(19), 6808-6820.

[57] De Muynck, W., Verbeken, K., De Belie, N., \& Verstraete, W. (2013). Influence of temperature on the effectiveness of a biogenic carbonate surface treatment for limestone conservation. Applied microbiology and biotechnology, 97(3), 1335-1347.

[58] Atlas, R. M., Chowdhury, A. N., \& Gauri, K. L. (1988). Microbial calcification of gypsum-rock and sulfated marble. Studies in conservation, 33(3), 149-153.

[59] Gauri, K. L., \& Bandyopadhyay, J. K. (1999). Carbonate stone: chemical behavior, durability and conservation.

[60] Wang, J., Van Tittelboom, K., De Belie, N., \& Verstraete, W. (2012). Use of silica gel or polyurethane immobilized bacteria for self-healing concrete. Construction and building materials, 26(1), 532-540.

[61] Bang, S. S., Galinat, J. K., \& Ramakrishnan, V. (2001). Calcite precipitation induced by polyurethane-immobilized Bacillus pasteurii. Enzyme and microbial technology, 28(45), 404-409.
[62] Van Tittelboom, K., De Belie, N., De Muynck, W., \& Verstraete, W. (2010). Use of bacteria to repair cracks in concrete. Cement and Concrete Research, 40(1), 157-166.

[63] De Belie, N., \& De Muynck, W. (2008, November). Crack repair in concrete using biodeposition. In Proceedings of the International Conference on Concrete Repair, Rehabilitation and Retrofitting (ICCRRR), Cape Town, South Africa (pp. 291-292).

[64] Wiktor, V., \& Jonkers, H. M. (2011). Quantification of crack-healing in novel bacteriabased self-healing concrete. Cement and Concrete Composites, 33(7), 763-770.

[65] Jonkers, H. M., \& Schlangen, E. (2008). Development of a bacteria-based self healing concrete. In Proc. int. FIB symposium (Vol. 1, pp. 425-430).

[66] Wang, J. Y., Soens, H., Verstraete, W., \& De Belie, N. (2014). Self-healing concrete by use of microencapsulated bacterial spores. Cement and Concrete Research, 56, 139-152.

[67] Joshi, S., Goyal, S., Mukherjee, A., \& Reddy, M. S. (2019). Protection of concrete structures under sulfate environments by using calcifying bacteria. Construction and Building Materials, 209, 156-166.

[68] Mittermayr, F., Rezvani, M., Baldermann, A., Hainer, S., Breitenbücher, P., Juhart, J.,. \& Proske, T. (2015). Sulfate resistance of cement-reduced eco-friendly concretes. Cement and Concrete Composites, 55, 364-373.

[69] Najjar, M. F., Nehdi, M. L., Soliman, A. M., \& Azabi, T. M. (2017). Damage mechanisms of twostage concrete exposed to chemical and physical sulfate attack. Construction and Building Materials, 137, 141-152.

[70] Aye, T., \& Oguchi, C. T. (2011). Resistance of plain and blended cement mortars exposed to severe sulfate attacks. Construction and Building Materials, 25(6), 2988-2996.

[71] Lee, B. Y., \& Kurtis, K. E. (2017). Effect of pore structure on salt crystallization damage of cementbased materials: Consideration of $\mathrm{w} / \mathrm{b}$ and nanoparticle use. Cement and Concrete Research, 98, 61-70.

[72] Mihashi, H., \& Nishiwaki, T. (2012). Development of engineered self-healing and selfrepairing concrete-state-of-the-art report. Journal of Advanced Concrete Technology, 10(5), 170-184.

[73] Siddique, R., \& Chahal, N. K. (2011). Effect of ureolytic bacteria on concrete properties. Construction and building materials, 25(10), 3791-3801.

[74] Khaliq, W., \& Ehsan, M. B. (2016). Crack healing in concrete using various bio influenced selfhealing techniques. Construction and Building Materials, 102, 349-357. 
[75] Achal, V., Mukerjee, A., \& Reddy, M. S. (2013). Biogenic treatment improves the durability and remediates the cracks of concrete structures. Construction and Building Materials, 48, 1-5.

[76] Maes, M., \& De Belie, N. (2014). Resistance of concrete and mortar against combined attack of chloride and sodium sulphate. Cement and Concrete Composites, 53, 59-72.

[77] Nehdi, M., \& Hayek, M. (2005). Behavior of blended cement mortars exposed to sulfate solutions cycling in relative humidity. Cement and Concrete Research, 35(4), 731-742.

[78] Najjar, M. F., Soliman, A. M., \& Nehdi, M. L. (2014). Critical overview of two-stage concrete: Properties and applications. Construction and Building Materials, 62, 47-58.

[79] Liu, Z., Deng, D., \& De Schutter, G. (2014). Does concrete suffer sulfate salt weathering?. Construction and Building Materials, 66, 692-701.

[80] Scherer, G. W. (2004). Stress from crystallization of salt. Cement and concrete research, 34(9), 16131624.
[81] Zhang, Y., Guo, H. X., \& Cheng, X. H. (2015). Role of calcium sources in the strength and microstructure of microbial mortar. Construction and Building Materials, 77, 160-167.

[82] Xu, J., \& Yao, W. (2014). Multiscale mechanical quantification of self-healing concrete incorporating non-ureolytic bacteria-based healing agent. Cement and concrete research, 64, 1-10.

[83] Nosouhian, F., Mostofinejad, D., \& Hasheminejad, H. (2015). Concrete durability improvement in a sulfate environment using bacteria. Journal of Materials in Civil Engineering, 28(1), 04015064.

[84] Chahal, N., Siddique, R., \& Rajor, A. (2012). Influence of bacteria on the compressive strength, water absorption and rapid chloride permeability of fly ash concrete. Construction and Building Materials, 28(1), 351-356.

[85] Vijay, K., Murmu, M., \& Deo, S. V. (2017). Bacteria based self healing concrete-A review. Construction and Building Materials, 152, 1008-1014.

How to cite this manuscript: Onesmus Mulwa Munyao, Joseph Karanja Thiong'o, Jackson Muthengia Wachira, Daniel Karanja Mutitu, Mwirichia Romano, Genson Murithi, Use of Bacillus Species Bacteria in Protecting the Concrete Structures from Sulphate Attack-A Review, Journal of Chemical Reviews, 2019, 1(4), 287-299. 